\title{
Somut Olmayan Kültürel Mirasın Korunması Bağlamında Türkiye'de Eğitim Alanında Yapılan Bilimsel Çalışmalar Üzerine Bir Bibliyografya Denemesi
}

\author{
*Doç. Dr. Sibel TURHAN TUNA \\ Muğla Sıtkı Koçman Üni. Ĕ̌gitim Fak. Sosyal Bilimler ve Türkçe Eğitimi Bölümü, Türkçe Eğitimi ABD, \\ sibeltuna@mu.edu.tr \\ **Elif Saral \\ Muğla Sitkı Koçman Üni. Ĕ̈itim Bilimleri Enst. Yüksek Lisans Öğrencisi, \\ elifkayasaral@gmail.com
}

DOI: $10.21666 /$ muefd. 354350

\begin{abstract}
Özet
Kültür, bir toplumun yaşam tarzının, atalarından gelen örf, adet ve geleneklerinin, değerlerinin, bir başka ifadeyle o toplumun ürettiğinin toplamıdır. Milletlerin varlığını sürdürebilmesi ve kültürel mirasını koruyarak gelecek nesillere aktarabilmesi için kültürel değerlerinin farkında olması gerekmektedir. Yirminci yüzyllın sonlarına doğru tüm dünyayı etkisi altına almaya başlayan küreselleşme, toplumları milli kültüründen uzaklaştırmaya ve tek tipleştirmeye doğru götürmektedir. UNESCO'nun 32. Genel Konferansinda 17 Ekim 2003 tarihinde imzalanan Somut Olmayan Kültürel Mirasın Korunması Sözleşmesi ile bu konuya dikkat çekilmek istenmiş olup sözleşme ile somut olmayan kültürel mirasın aktarllmasında taşıyıcı işlevi gören dille birlikte sözlü gelenekler, anlatımlar; gösteri sanatlarl; toplumsal uygulamalar, ritüeller ve şölenler; doğa ve evrenle ilgili bilgi ve uygulamalar; el sanatlart geleneği somut olmayan kültürel miras olarak belirlenmiştir. Somut olmayan kültürel mirasın kaybolması konusunda evrensel bir kaygının olduğu belirtilerek konunun önemi hususunda farkındalı̆̆ artırmak ve yeni nesilleri bilinçlendirmek amacıyla taraf devletlerin dayanışma içerisinde bu mirasın korunmasına katkıda bulunması hedeflenmiştir. Türkiye, 2006 yılında bu sözleşmeye taraf devlet olmuştur. Bu çalışmada, Somut Olmayan Kültürel Mirasın Korunması Sözleşmesi alanında, 2006 yılından günümüze kadar "eğitim” alanında yapılmış olan çalışmaların bibliyografyası sunulmuştur. Çalışmada nitel araştırma yöntemlerinden doküman tarama yöntemi kullanılmıştır. Tarama sonucunda elde edilen eserlerin dağılımına bakıldı̆̆ında 3 lisansüstü tez, 25 makale, 10 bildiriye ulaşılmış olup çalışmada ayrıca lisansüstü üç tezin analizi yapılmıştır. Tespit edilen çalışmalar incelendiğinde somut olmayan kültürel mirasın korunması bağlamında milli duyarlılı̆̆ın artırllması gerektiği ve ĕgitim-ögretim kurumlarında sistemli ve planlı bir SOKÜM eğitimi verilerek bunun să̆lanabileceği konusu, çalışmaların neredeyse genelinin ortak bir sonucu olduğu kanaatine varılmıştır.
\end{abstract}

Anahtar Sözcükler: Türkiye, SOKÜM, Halk Bilimi, Ĕ̆itim, Bilimsel Çalışmalar, Bibliyografya

\section{A Bibliographical Study on The Scientific Studies on Safeguarding Intangible Cultural Heritage in Turkey}

\begin{abstract}
Culture is an accumulation of a society's way of life; the traditions, customs and values it inherited, in other words everything that society produced. A society needs to be aware of its cultural values in order for it to survive and pass its culture unto the next generations by preserving it. Globalization, which began to be effective in the whole world since the end of the twentieth century has been leading societies away from their national culture into uniformity. The 32nd General Conference of UNESCO aimed at drawing attention to this issue by adopting the Convention to Safeguard Intangible Cultural Heritage on 17 October 2003. Through this convention, along with language, which is the vehicle of transferring intangible cultural heritage, oral traditions, narrations, performance arts, communal activities, rituals and festivals, activities concerning nature and the universe and handicrafts have been deemed intangible cultural heritages. By announcing a universal concern of the loss of intangible cultural heritage, the convention aims at getting the interested countries to contribute to the safeguarding of this heritage in order to raise awareness and to inform the younger generations. Turkey became an interested country in 2006. This study presents a bibliography of the studies on intangible cultural heritage in the education field up to date. In this study, of the qualitative research methods the document scanning method was used. 3 theses, 22 articles and 7 oral presentations matched with the scans. When these studies were analysed, the common conclusion of almost all of them was that the national awareness in terms of intangible cultural heritage must be raised and that this can be achieved through a systematic and well-planned intangible cultural heritage education in the curriculum.
\end{abstract}

Key words: Turkey, Intangible Cultural Heritage, Education, Folklore, Scientific Research, Bibliography 
Teknolojideki hızlı ilerlemeyle birlikte tüm dünyada toplumları ekonomik, sosyal, kültürel alanlarda etkileyen geniş çaplı değişiklikler meydana gelmektedir. N. Topçu'ya göre, günümüz dünyasında teknik hakimdir ve teknolojik gelişmeler nedeniyle eşyanın insan üzerindeki zaferi gerçekleşmiştir (Topçu, 2016: 23). Teknikte meydana gelen ilerlemeler toplumların ekonomik gelişimine katk1 sağlamış, bununla birlikte kültürel değerlerinin zarar görmesine hatta yok olmasına sebep olmuştur. Teknoloji ve teknolojinin getirdiği maddi güç toplumda maddi açıdan refah sağlayabilir, ama toplumu bir arada tutan şey maddiyat değil millet olma bilincidir (Anadol vd., 2002: 37). Teknolojinin gelişmesiyle birlikte kitle iletişim araçları küçükten büyüğe toplumun bütün fertleri tarafindan yoğun bir şekilde kullanılmaya başlanmıştır. E. Kolaç, bu durumun toplumların farklı kültürleri tanıma ve iletişim kurma anlamında düşünüldügünde olumlu gibi göründüğünü, ancak yerel kültürlerin bu etkileşimden olumsuz yönde etkilendiğini, toplumlara ait kültürel mirasların yok olma tehlikesiyle karş1 karşıya kaldığını belirtmiştir (Kolaç, 2009: 20). Nitekim küreselleşme sürecinde kültürler ve toplumlar arasındaki, "sözlü-yazılı", "ilkel-modern”, "geri kalmış-gelişmiş” veya "köylü-kentli” şeklindeki farklar ortadan kalkar ve kültürler tek tipleştirici bir olgu olarak ortaya çıkar (Oğuz, 2008: 5-6). Tüm bu hususta yapılması gereken, yüzyılları aşıp gelen kültürel değerlerimizi küreselleşmenin yıkıcı etkisinden koruyabilmek, onların naklini sağlayabilmek, genç kuşakları bu konuda bilinçlendirmektir.

Kuşaklar arası nakil, elbette bir milletin ana dili ile gerçekleşecektir. Ana dili ve milli kültürü ile sosyal bir varlık olan insan, yaşamı boyunca onu mutlu eden, heyecanlandıran olaylarla karşılaştığı gibi büyük afetler, savaşlar yahut ölümlerle de karşılaşabilir. Böyle durumlarda milleti ayakta tutan değerler, kültürel değerlerdir. Tarihi, toplumsal gelişme süreci içinde yaratılan bütün maddi ve manevi değerler ile bunları yaratma, sonraki nesillere iletmede kullanılan insanın doğal ve toplumsal çevresine egemenliğinin ölçüsünü gösteren araçların bütünü (Türkçe Sözlük - II, 1998: 1436) olan kültür, milletin geleceği açısından çok önemli bir yere sahiptir. Nitekim milletler; gelişmek, büyümek, medenileşmek için bilimsel, ekonomik ve teknolojik alanda çalışmalar yapmaktadırlar. Ziya Gökalp'e göre bir medeniyetteki bilimsel, ekonomik ve teknolojik gelişmeler, taklit ve değiştirme yoluyla bir toplumdan başka topluma geçer ve böylece, bir medeniyet toplumu önce bölgesel bir biçimde görünür, zamanla ülkeleri, kıtaları ve bütün insanlığı sarar (Gökalp, 2013: 140). Milletlerin bu sürece sirt dönmesi beklenemez, yalnız dikkat edilmesi gereken; milletin geçmişten günümüze gelmesine ve gelecekte de var olmasına imkan veren millî kültürün, çağın gereklerine uyum sağlama sürecinde bir başka ifadeyle, değişim veya dönüşüm sürecinde, yozlaşmasına yitip gitmesine izin verilmemelidir.

Kültürümüzün taşıyıcısı olan günümüz gençliğinin temel sorunu milli kültür unsurlarını eski, modası geçmiş bularak beğenmemesi, popüler kültür etkisiyle büyümesidir. Günümüzde nüfusun büyük çoğunluğu şehirlerde yaşamaktadır ve çalışan kadınların oranında da büyük artış vardır. Bu sebeplerden dolayı kültürel ortamdan uzak büyüyen çocuklar, gençlik yıllarına geldiklerinde sözlü kültür ürünlerini, toplumsal uygulamaları modası geçmiş bulmakta ve beğenmemektedirler. Oysa Artun'un bildirdiğine göre çağdaş genç, milli kültürden kopmadan evrensel kültürde yerini alabilen insan tipidir. Bu nedenle de gençlere milli kültürle yoğrulmadan evrensel kültürde yer alınamayacağı bilinci verilmelidir (Artun, 2000: 2). Bireylerin kalabalıklar içinde yalnızlaşmamaları, milli kültürlerini koruyabilmeleri, geliştirmeleri ve gelecek nesillere taşıyabilmeleri için ilkokul yıllarından itibaren bilinçli ve sistemli bir eğitimden geçmeleri gerekmektedir. Türk milli eğitiminin temel amaçlarının ilk maddesinde "manevi değerleri korumak ve geliştirmek" ibaresi yer almaktadır. Ö. Oğuz, somut olmayan kültürel mirasın korunması konusunda halk bilimi ve halk kültürü konularının ilkokul, ortaokul ve liselerde ders olarak okutulmas1 gerektiğini belirtmektedir (Oğuz, 2013: 134). İlköğretim 7. Sınıf Halk Kültürü Öğretim Programı'nda kısa vadede, öğrencilerin halkın değer yargıları, hayatı ve dünyayı algılayış biçimi, olaylar karşısındaki tavır, tutum ve tepkileri konularında bilgi sahibi olmalarının amaçlandığı belirtilmektedir. Uzun vadede ise dünya genelinde ekonomik, politik gelişmelerin karşısında kendi kültürlerini tanımaları, tanıtmaları ve korumaları amaçlandığı belirtilmiştir (İlköğretim Halk Kültürü Dersi Öğretim Programı, 2007: 7). Bu bağlamda, Halk Kültürü dersi, 2006-2007 Eğitim Öğretim yılından 4+4+4 Eğitim Sistemi’nin uygulanmaya başladığı 2012-2013 Eğitim Öğretim yılına kadar 68. sinıflarda seçmeli ders olarak yer almıştır. Bu ders, sözü edilen dönemde yeni eğitim sistemine geçildikten sonra yine seçmeli statüde olmakla birlikte sadece 6 . ve 7. sınıflarda verilmeye başlamıştır (Aral, 2016: 117-118). 
Milli kültürün oluşmasında halk kültürünün öneminin ne kadar büyük olduğu düşünüldüğünde bu konuda eğitim kurumlarına çok büyük iş düştüğü görülmektedir. Bu konuda yapılacak çalışmalar ögrencilerin kültürlerini daha yakından tanımalarına, benimsemelerine ve kültürlerini koruma bilincine ulaşmalarına yardımcı olması bakımından oldukça önemlidir. V. Savaşkan, örgün anlamda okulda öğrenilen dil ve edebiyat derslerinin kültürün gelişimiyle bağlantılı olduğunu, edebiyat derslerinde kullanılan edebi eserlerin yalın türden bir nesne olmadığını, bu derslerin tarihsel, kültürel, toplumbilimsel değer taşıdığının göz önünde bulundurulması gerektiğini belirtmiştir (Savaşkan, 2016: 1304). Bu doğrultuda ders kitaplarında halk kültürü ürünlerine daha fazla yer verilmelidir ve çalışma kitaplarında yer alan etkinliklerle öğrencinin metni özümsemesi sağlanmalıdır. Kolaç’ın bildirdiğine göre ders metinlerinde; geleneksel el sanatları ve Ahilik geleneği, geleneksel Türk süsleme sanatları, Karagöz gibi geleneksel seyirlik oyunlar, Hıdırellez, sözlü edebiyat ürünleri (efsane vd.), geleneksel çocuk oyunları, Nevruz gibi somut olmayan kültür ögelerine yer verilmiştir (Kolaç, 2009: 30). Diğer yandan, okullarda milli kültürün eğitimi ve öğretimi konusunda daha verimli ve başarılı bir eğitim gerçekleştirebilmek için, eğitim teknolojilerinden de faydalanılmalıdır. Eğitim teknolojileriyle ders daha dikkat çekici hale getirilebilir ve öğrenciler sıkılmadan hatta öğrendiğini fark etmeden öğrenebilir (Kasapoğlu, 2016: 155). Öyle ki, sözlü ya da yazılı kültürü içeren milli kültür, Z kuşağı olarak da bilinen milenyum gençliğine teknolojik yöntemler kullanılarak daha verimli iletilecek ve karşılığında milli değerlerin ve bu bağlamda halk kültürünün hedef kitlede kazanımında başarı sağlanacaktır.

Hızla küreselleşme çarkına giren toplumların milli kültürlerini, gelenek ve göreneklerini unutmaya yüz tutması kaygı verici bir durumdur. M. Kutlu'ya göre halk kültürü, bir kültüre ait olan sözel ve geleneksel bütün unsurları içerir ve toplumun belleğini oluşturarak geçmişle geleceği birbirine bağlar (Kutlu, 2009: 15). Eğitim, bilim ve kültür alanında çalışmalar yapan Türkiye'nin de 1946'dan beri üye olduğu uluslararası bir kurum olan UNESCO, "SOKÜM Sözleşmesi” ile dünyayı monoton bir kültür yapısına götüren duruma dikkat çekerek, halk kültürünün korunmasının ve gelecek kuşaklara miras olarak bırakılmasının taraf devletlerin sorumluluğunda olduğunu vurgulamıştır (Okur, 2013: 891). UNESCO dünyadaki kültür çeşitliliğini korumak ve gelecek nesillere aktarabilmek amaciyla birçok çalışma yapmıştır. Bunlardan en fazla yankı uyandıranlar 1972 yılında imzalanan Kültürel ve Doğal Mirasın Korunması Sözleşmesi, 1989 yılında imzalanan Popüler ve Geleneksel Kültürün Korunması Tavsiye Kararı ve UNESCO'nun 32. Genel Konferansında 17 Ekim 2003 tarihinde imzalanan Somut Olmayan Kültürel Mirasın Korunması Sözleşmesi olarak sıralanabilir. Ö. Oğuz’un bildirdiğine göre sözleşme metninde Somut Olmayan Kültürel Miras şöyle tanımlanmıştır: "Somut Olmayan Kültürel Miras" toplulukların, grupların ve kimi durumlarda bireylerin, kültürel miraslarının bir parçası olarak tanımladıkları uygulamalar, temsiller, anlatımlar, bilgiler, beceriler ve bunlara ilişkin araçlar, gereçler ve kültürel mekânlar anlamına gelir (Oğuz, 2013: 233). Türkiye'nin 27 Mart 2006 tarihinde taraf olduğu Somut Olmayan Kültürel Mirasın Korunması Sözleşmesi'nin amaçları, teknolojik gelişmeler, göçler, popüler kültür, medya ve küreselleşme gibi dış nedenlerle yok olan sözlü kültürlere ait "somut olmayan miras" olarak tanımlanan kültür ürünlerini korumak ve doğduğu topluluk içinde yaşamalarına katkı sağlamaktır. Belirlenen bu amaçlar doğrultusunda korunması gereken somut olmayan kültürel miras alanları 2. maddenin 2. bendinde sözlü gelenekler ve anlatımlar, gösteri sanatları, toplumsal uygulamalar, ritüeller ve şölenler; doğa ve evrenle ilgili bilgi ve uygulamalar, el sanatları geleneği olarak belirlenmiştir (Oğuz, 2005: 54-164).

Çalışmanın amacı, halk bilimi ve dâhilinde "Eğitim" ve "Somut Olmayan Kültürel Miras" alanında araştırmacılara, veri tarama yönteminden yararlanarak bilimsel bir çalışmanın da ilk basamağını oluşturan genel bir bibliyografya sunabilmektir. Bu sebeple, Somut Olmayan Kültürel Mirasın Korunması Sözleşmesi bağlamında YÖK tez tarama sitesinden, Google Akademik ve Yök Akademik web sitelerinden faydalanılarak Eğitim alanına yönelik Türkçe yayımlanan ve halihazırda ulaşılmaya çalışılan yüksek lisans tezlerinin, makalelerin ve bildirilerin tam künyelerine yer verilmeye çalışılmıştır. Ayrıca çalışmada, lisansüstü tezler üzerine analizli bir bibliyografya denemesi de yapılmıştır. Çalışmanın engin konusu, elbette makalenin boyutları açısından bakıldığında, sadece Eğitim alanında ele alınabilmiştir. Tüm bu bilgilere ek olarak, halihazırda, sosyal ve beşeri disiplinlerde SOKÜM alanında yapılan geriye dönük tüm bilimsel araştırmalar analizli yüksek lisans tezi olarak planlanmış olup üzerinde çalışmalar sürdürülmektedir. Böylece, tüm bu araştırmalarla hem konu ile ilgili yeni çalışmalar 1şığında, güncel veri havuzu kurulması hem de son dönem dahil geriye dönük ulaşılmaya çalışılan bilimsel çalışmalar, eleştirel anlamda ele alınarak alana katkı sağlanması hedeflenmektedir. 


\section{Lisansüstü Tezler}

\section{Gürkan, B. (2015). Sosyal Bilgiler Ders Kitaplarının Somut Olmayan Kültürel Miras Açısından İncelenmesi. Çukurova Üniversitesi Sosyal Bilimler Enstitüsü, Yüksek Lisans Tezi, Adana.}

Bu çalışma, sosyal bilgiler ders kitaplarında somut olmayan kültürel mirasın yerini belirlemek amacıyla yapılmıştır. Küreselleşmenin etkisiyle yok olmaya başlayan somut olmayan kültürel miras konusunda yeterli çalışma yapılmadığı belirtilmiştir. Eğitimin de kültür gibi küreselleşmenin olumsuz etkisine açık olduğuna değinilerek Sosyal Bilgiler Öğretim Programı'nın da bu nedenden ötürü 2005 yılında yeniden düzenlendiği ifade edilmiştir. Türkiye'nin 2006 yılında taraf olduğu SOKÜM Sözleşmesi'nin eğitime yönelik çalışmaları olduğu vurgulanmıştır. Ülkemizde de Milli Eğitim Bakanlığı'nın bu sözleşme doğrultusunda ilköğretim okullarına seçmeli olarak halk kültürü dersi koyduğu ve dersin 2006-2007 eğitim-öğretim yılında uygulamaya geçtiği belirtilmiştir. Sosyal bilgiler dersinin de SOKÜM ile birçok ortak noktası olduğu, program incelendiğinde bu ortak noktaların görülebileceği ifade edilmiştir. Eğitim ve kültürün yakın ilişkisinin okullarda ve okullarda okutulan ders kitaplarında kendisini göstermek durumunda olduğu belirtilerek sosyal bilgiler ve Türkçe ders kitaplarının kültür ve kültürel miras gibi kavramların aktarılmasında önemli bir araç olduğu ifade edilmiştir. Bu doğrultuda 4, 5, 6, 7 ve 8. sınıf sosyal bilgiler ders kitaplarındaki kazanım ve konularda SOKÜM unsurları nasıl ve ne kadar yer almaktadır sorusu ile Sosyal Bilgiler ders kitaplarında SOKÜM'ün "somut olmayan kültürel mirasın aktarılmasında taşıyıcı işlevi gören dille birlikte sözlü gelenekler ve anlatımlar; gösteri sanatları; toplumsal uygulamalar, ritüeller ve şölenler; doğa ve evrenle ilgili bilgi ve uygulamalar; el sanatları geleneği" boyutlarından hangileri yer almaktadır sorusuna yanıt aranmıştır.

Diğer bölümde ise kuramsal bilgilere yer verilmiştir. "Sosyal Bilgiler Öğretim Programı", "UNESCO ve Kurumsal İşlevi”, "Kültür ve Kültürel Miras Kavramları", "Doğal ve Kültürel Dünya Mirasının Korunması Sözleşmesi”, "Sualtı Kültürel Mirasının Korunması Sözleşmesi”, "Somut Olmayan Kültürel Miras", "Yaşayan İnsan Hazineleri Programı, İnsanlığın Sözlü ve Somut Olmayan Mirası Başyapıtları İlanı", Somut Olmayan Kültürel Mirasın Korunması Sözleşmesi”, "Somut Olmayan Kültürel Mirasın Boyutları", "Somut Olmayan Kültürel Mirasa Yönelik Tehditler", "Somut Olmayan Kültürel Miras ve Eğitim", "Örgün Eğitimde Somut Olmayan Kültürel Miras" başlıkları altında ayrıntılı bilgi verilmiştir. Tarama tekniği kullanılan çalışmanın temel dokümanları, Milli Eğitim Bakanlığı'na bağlı ilk ve ortaokulların Koyuncu Kaya (2012) tarafından hazırlanan (Ed. Demircioğlu) İlköğretim 4. Sınıf Sosyal Bilgiler Ders ve Çalışma Kitabı; Başol vd. (2012) tarafından hazırlanan (Ed. Baltacıoğlu) İlköğretim 5. Sınıf Sosyal Bilgiler Ders ve Çalışma Kitabı; Komisyon (2012) tarafından hazırlanan (Ed. Köstüklü) İlköğretim 6. Sınıf Sosyal Bilgiler Ders ve Çalışma Kitabı ve Komisyon (2012) tarafından hazırlanan (Ed. Güven) İlköğretim 7. Sınıf Sosyal Bilgiler Ders ve Çalışma Kitabı ders kitapları olduğu belirtilmiştir. $\mathrm{Bu}$ doğrultuda, ders kitapları somut olmayan kültürel miras öğeleri açısından incelenmiştir.

Ders kitapları araştırmacı tarafından SOKÜM vurgularına göre incelenerek SOKÜM boyutlarıyla ilgili bilgi ve görseller tespit edilmiştir. Bunlar, Sosyal Bilgiler öğretim programlarındaki kazanımlar ve ders kitaplarındaki ünite ve konulara göre sınıflandırılmıştır. Bu sınıflandırma sonucu ders kitaplarındaki SOKÜM boyutlarını içeren bilgiler tablolaştırılmıştır.

Dördüncü sınıf sosyal bilgiler ders kitaplarından elde edilen bulgular incelendiğinde SOKÜM'ün aktarılmasında taşıyıcı işlevi gören dille birlikte sözlü gelenekler ve anlatımlar boyutunun içinde yer alan efsaneler ve atasözlerinden örneklere yer verildiği, yalnız verilen atasözlerinin yabancı atasözleri olduğu belirtilmiştir. Gösteri sanatları boyutunda Hacivat-Karagöz, sema gösterisi, çocuk oyunları, cirit ve Kırkpınar yağlı güreşlerinin yer aldığı belirtilmiştir. Toplumsal uygulamalar, ritüeller ve şölenler boyutunda kına, diş hediği kutlamaları ve asker uğurlama törenlerine yer verildiği ifade edilmiştir. Doğa ve evrenle ilgili uygulamalar boyutunun içerisinde yer alan mutfak kültüründeki yiyecek-içecekler ve uygulamaların ders kitabında resimlerle ve anlatımlarla yer aldığı belirtilmiştir. El sanatları geleneği boyutunun içerisinde yer alan çevre (mendil), ebru sanatı, para kesesi, kilim ve alaca dokumacılığının ders kitabında yer aldığı belirtilmiş̧ir. 4. sınıf ders kitaplarının neredeyse genelinde SOKÜM konusuna doğrudan vurgu yapılmadığı, kültür vurgusunun ulusal ve tarihsel açıdan değerlendirildiği belirtilmiştir. SOKÜM'ün evrensel boyutuna bir ünitede yer verildiği ifade edilmiştir.

Beşinci sınıf sosyal bilgiler ders kitaplarında somut olmayan kültürel mirasın aktartılmasında taşıyıcı işlevi gören dille birlikte sözlü gelenekler ve anlatımlar boyutunun içinde yer alan fikra, türkü, atasözü, 
mani, tekerleme, deyim ve âşıklık geleneğinin ders kitaplarında yer aldığ 1 tespit edilmiştir. Gösteri sanatları boyutunda halk oyunları geleneğine yer verildiği belirtilmiştir. Toplumsal uygulamalar, ritüeller ve şölenler boyutunda, ders kitabında Hıdırellez, Nevruz, bayramlar ve âşılık geleneğinin yer aldığ 1 ifade edilmiştir. Doğa ve evrenle ilgili uygulamalar boyutunun içerisinde yer alan mutfak kültürüne Türkiye'deki çeşitli illerden örnekler verilerek yer verildiği belirtilmiştir. Beşinci sınıf ders kitaplarında SOKÜM' ün beş boyutuna SOKÜM farkındalığı oluşturulmadan değinildiği ifade edilmiştir.

Altıncı sınıf ders kitaplarında gösteri sanatları boyutu ile ilgili sadece Çevgan oyununu gösteren bir minyatür verildiği belirtilerek yetersiz bulunmuştur. El sanatları geleneği boyutu içerisinde Pazırık Halısı ve maden işlemeciliğine verildiği belirtilmiştir. Toplumsal uygulamalar, ritüeller ve şölenler boyutunda, Türklerde bahar bayramının (nevruz) ortaya çıkışı, düğün gelenekleri ve mesir macunu festivalleri gibi ritüel ve şölenlere değinilmiştir. Altıncı sınıf ders kitaplarında SOKÜM'ün üç boyutuna yer verildiğine dikkat çekilmiştir.

Yedinci sınıf sosyal bilgiler ders kitaplarında somut olmayan kültürel mirasın aktartılmasında taşıyıcı işlevi gören dille birlikte sözlü gelenekler ve anlatımlar boyutunun içinde yer alan atasözü, deyim ve türküler kullanıldığı açıklanmıştır. Toplumsal uygulamalar, ritüeller ve şölenler boyutu ile ilgili ramazan bayramı ve düğünlere yer verildiği ifade edilmiştir. Gösteri sanatları boyutu ile ilgili cirit, güreş, okçuluk ve sema gösterisi öğelerinin kısa bilgiler ve resimlerle yer bulduğu ifade edilmiştir. Doğa ve evrenle ilgili uygulamalar boyutunun içerisinde yer alan kahve kültürünün ders kitaplarında ayrıntılı bir şekilde yer bulduğu ve yer sofrası kültürüne değinildiği belirtilmiştir. El sanatları geleneği boyutunun içerisinde ahşap işlemeciliğine bir örnek metinle yer verildiği ifade edilmiştir. Yedinci sınıf ders kitaplarının Türkiye'nin UNESCO'nun ortak miras listesine alınan ve alınmayan yapılarına dikkat çektiği vurgulanmıştır.

Öneriler kısmında ders kitaplarında somut olmayan kültürel miras ifadesine yer verilmesi gerektiğine, SOKÜM'ün beş boyutuna verilen örneklerin yetersiz olduğuna, SOKÜM konularının tek bir üniteye sıkıştırılmaması gerektiği, ünite sonlarında kazanımların değerlendirilmesi gerektiğine, etkinlik kitaplarında konuyla ilgili etkinliklerin yer alması gerektiğine, sadece Türkiye'nin miras listesine değil, sınıf düzeylerine göre farklı ülkelerin miras listelerine de yer verilmesi gerektiğine, insanlığın somut kültürel mirası hakkında da bir farkındalık yaratılması gerektiğine dikkat çekilmiştir.

Tüm bu verilen bilgilerden sonra çalışmada, Sosyal Bilgiler ders kitaplarının (2012- 4,5,6,7. Sınıflar) SOKÜM'ün beş temel madde etrafında ayrıntılı incelenmesi sonucu bazı öneriler sunulduğu dikkati çekmektedir. Her şeyden önce, Türkçe Ders kitaplarında da bu türden bir çalışmanın yüksek lisans veya doktora düzeyinde yapılması beklenirdi. Bu bakımdan çalışma, lisans üstü bir çalışma konusu olarak da ülkede ilki temsil etmiştir. Diğer taraftan, sınıf düzeyleri açısından bakıldığında beş ana madde ve örnek dağılımı konusunun biraz daha tartışmaya açık olduğunun altı çizilmelidir. Nitekim Türkçe ders kitaplarına da temalar ve üniteleri bağlamında bakıldığında, yukarıda bahsi geçen maddelerin örneklerine yer verildiği bilinmektedir. Bu bağlamda, hem İlköğretim Sosyal Bilgiler hem de Türkçe ders kitaplarının SOKÜM konusunun paralel, koordineli olarak ele almasının konu alanlı ders kitaplarının niteliği, öğrenci kazanımları ve eğitim hayatındaki yeri bakımından önemli olduğunun altı çizilebilir.

\section{Pehlivan, A. (2015). Açık ve Örgün Eğitim Sosyal Bilgiler Ders Kitapları ve Öğretim Programinda Somut Olmayan Kültürel Miras Ögelerinin İncelenmesi. Anadolu Üniversitesi Eğitim Bilimleri Enstitüsü, Yüksek Lisans Tezi, Eskişehir.}

$\mathrm{Bu}$ çalışmada, ortaokul açık öğretim ve örgün eğitim sosyal bilgiler ders kitapları ve öğretim programında SOKÜM ögelerinin incelenmesi amaçlanmıştır. Kültürel mirasın korunması ve gelecek nesillere aktarılmasında bireylerin ve bireylerin kültür konusundaki farkındalığının önemli olduğu belirtilmiştir. Derslerin amaçlarında ve öğretim programlarında kültürel mirasın korunmasına yer verilmesinin yeterli olmadığ materyalleri, kullanılan yöntem ve tekniklerle de desteklenmesi gerektiği belirtilmiştir. Milli kültürün korunabilmesi için SOKÜM Sözleşmesi kapsamında halk kültürü dersinin ortaokullarda seçmeli ders olarak okutulmaya başlandığı açıklanarak SOKÜM kapsamındaki konuların Sosyal Bilgiler dersinde de yer aldığ 1 ifade edilmiştir. Kültürel öğeleri korunma bilincinin sadece örgün eğitimde değil yaygın eğitimde de verilmesi gerektiği, istatistiklere bakıldığında yaygın eğitimdeki öğrenci sayısının 250 bini 
aştığı ifade edilmiştir. Tüm bu sebeplerle de araştırmada, örgün eğitim ve Açık Öğretim Sosyal Bilgiler dersi materyalleri bir arada incelenmiştir. Temel amaç doğrultusunda; Ortaokul Sosyal Bilgiler Öğretim Programları'nda SOKÜM ögelerine yer verilme durumu nasıldır, ortaokul örgün eğitim Sosyal Bilgiler ders kitaplarında SOKÜM ögelerine yer verilme durumu nasıldır, ortaokul Açık Öğretim Sosyal Bilgiler ders notlarında SOKÜM ögelerine yer verilme durumu nasıldır, ortaokul örgün eğitim Sosyal Bilgiler ders kitapları ve Açık Öğretim ders notlarını SOKÜM ögelerine yer verilme durumu açısından birbirleriyle uygunluğu nasıldır, sorularına yanıt arandığı belirtilmiştir. "Sosyal Bilgiler: Tanımı ve Tarihçesi", "İlköğretim Programında Sosyal Bilgiler", "Sosyal Bilgiler Öğretiminde Kültürel Miras Eğitimi”, "Sosyal Bilgiler Öğretiminde Somut Kültürel Miras", "Sosyal Bilgiler Öğretiminde Somut Olmayan Kültürel Miras (SOKÜM)", "SOKÜM Ögeleri", "Örgün Eğitim Sosyal Bilgiler Dersinde SOKÜM", "Açık Öğretim Sosyal Bilgiler Dersinde SOKÜM” başlıkları altında çalışma konusu ele alınmıştır. Araştırmada Somut Olmayan Kültürel Mirasa ilişkin Türkiye'de ve dünyada yapılan çalışmalar iki başlık altında incelenmiştir.

Araştırmada kullanılan dokümanlar; Talim Terbiye Kurulu tarafından hazırlanmış Sosyal Bilgiler 5. Sınıf Öğretim Programı, Talim Terbiye Kurulu tarafından hazırlanmış Sosyal Bilgiler 6-7. Sınıf Öğretim Programları, Talim Terbiye Kurulunun 18.12.2009 gün ve 290 sayılı kararı ile beş yıllığına ders kitabı olarak kabul edilmiş 5. sınıf sosyal bilgiler ders kitabı, Talim Terbiye Kurulunun 17.12.2010 gün ve 239 sayılı kararı ile beş yıllığına ders kitabı olarak kabul edilmiş 6 . sınıf sosyal bilgiler ders kitabı, Talim Terbiye Kurulunun 08.12.2011 gün ve 258 sayılı kararı ile beş yıllığına ders kitabı olarak kabul edilmiş 7. sınıf sosyal bilgiler ders kitabı, Milli Eğitim Bakanlığı Hayat Boyu Öğrenme Genel Müdürlüğü internet sayfasında yer alan ve açık erişimli olan açık öğretim 6. ve 7. sınıf ders notları döküman analizi yöntemiyle incelenmiştir.

Elde edilen bulgular incelendiğinde, Ortaokul Sosyal Bilgiler Öğretim Programları'nda SOKÜM ile ilgili olarak toplam 25 kazanım yer aldığı, kazanımlara en fazla 7. Sınıf Öğretim Programı'nda yer verildiği, 5. ve 6. Sınıf Sosyal Bilgiler Öğretim Programları'nda yer verilen kazanımların eşit sayıda olduğu belirtilmiştir. SOKÜM ile ilgili etkinlik örnekleri incelendiğinde, ortaokul Sosyal Bilgiler Öğretim Programları'nda toplam 40 etkinlik örneğinin bulunduğu belirtilmiştir. Etkinlik örneklerinin en fazla 7. Sınıf Sosyal Bilgiler Öğretim Programı'nda yer aldığı, sonra sırasıyla 6. ve 5. sınıfların geldiği ifade edilmiştir.

5. sınıf örgün eğitim sosyal bilgiler ders kitabı SOKÜM ögeleri açısından incelendiğinde; ders kitabında beş ögenin de bulunduğu belirtilmiştir. En fazla "sözlü gelenekler ve anlatımlar" (7) ögesine yer verildiği; bu ögeyi sırasıyla, "toplumsal uygulamalar, ritüeller ve şölenler" (6), doğa ve evrenle ilgili bilgi ve uygulamalar" (3), "gösteri sanatları" (3) ögelerinin takip ettiği ve en az "el sanatları geleneği" (2) ögesine yer verildiği belirtilmiştir.

6. Sınıf Sosyal Bilgiler ders kitabı SOKÜM ögeleri açısından incelendiğinde; ders kitabında beş ögeden dördüne yer verildiği gösteri sanatları ögesinin ders kitabında yer almadığı belirtilmiştir. Metin dağılımı bakımından en fazla "sözlü gelenekler ve anlatımlar" (7) ögesine yer verildiği; bu ögeleri sirasıyla "toplumsal uygulamalar, ritüeller ve şölenler" (5), "doğa ve evrenle ilgili bilgi ve uygulamalar" (4) ve "el sanatları geleneği” (1) ögelerinin takip ettiği belirtilmiştir.

7. Sınıf Sosyal Bilgiler ders kitabı SOKÜM ögeleri açısından incelendiğinde; ders kitabında beş ögeye de yer verildiği belirtilmiştir. Metin dağılımı bakımından en fazla "doğa ve evrenle ilgili bilgi ve uygulamalar" (4) ögesine yer verildiği; bu ögeleri sırasıyla "sözlü gelenekler ve anlatımlar" (4), "toplumsal uygulamalar, ritüeller ve şölenler" (3), "el sanatları geleneği” (2) ve "gösteri sanatları" (1) ögelerinin takip ettiği belirtilmiştir.

6. sınıf Açık Öğretim Sosyal Bilgiler ders notları SOKÜM ögeleri açısından incelendiğinde; ders notlarında beş ögeden dördüne yer verildiği "gösteri sanatları" ögesinin ders notunda yer almadığ 1 belirtilmiştir. Metin dağılımı bakımından en fazla "sözlü gelenekler ve anlatımlar" (4) ögelerine yer verildiği; bu ögeleri sırasıyla "toplumsal uygulamalar, ritüeller ve şölenler" (3), "doğa ve evrenle ilgili bilgi ve uygulamalar" (1) ve "el sanatları geleneği”" (1) ögelerinin takip ettiği belirtilmiştir.

7. sınıf Açık Öğretim Sosyal Bilgiler ders notları SOKÜM ögeleri açısından incelendiğinde; beş ögeden üçüne yer verildiği; "sözlü gelenekler ve anlatımlar" ile "gösteri sanatları" ögelerinin ders notlarında yer almadığ 1 belirtilmiştir. Metin dağılımı bakımından en fazla "doğa ve evrenle ilgili bilgi ve uygulamalar" (4) ögesine yer verildiği; bu ögeleri sirasiyla "toplumsal uygulamalar, ritüeller ve şölenler" (2) ve "el sanatları geleneği” (2) ögelerinin takip ettiği belirtilmiştir. 
Açık Öğretim ortaokul Sosyal Bilgiler ders notlarında SOKÜM ögelerine üç sınıf düzeyinde de yer verilirken en fazla 5. sınıf ders kitabında vurgu yapıldı̆̆ gözlenmiştir. Bunları sırasıyla 6. sınıf ve 7. sınıf ders notlarının takip ettiği ifade edilmiştir. Program boyutunda en fazla kazanımın 7. sınıfta olduğu tespit edilmekle beraber ders içeriği boyutunda da en az etkinliğin 7. sınıfta olduğu belirlenmiştir. Elde edilen bulgulardan yola çıkarak açı öğretim programı ile açık öğretim ders notları arasında SOKÜM'e yer verme açısından bir tezatlık olduğu vurgulanmıştır.

Ortaokul örgün eğitim Sosyal Bilgiler ders kitapları ile Açık Öğretim ders notlarının SOKÜM ögelerine yer verilme durumu açısından karşılaştırılmasında ise neredeyse yarı yarıya bir fark olduğu ortaya konulmuştur.

Öneriler kısmında SOKÜM öğelerinin dağılımında çeşitliliğin sağlanmasına dikkat edilmesi, kazanım ve açıklamalarda SOKÜM vurgusunun açık bir şekilde yapılması, SOKÜM ögelerinin tüm ünitelerle ilişkilendirilmesi, açık öğretim ve örgün eğitimde SOKÜM ögelerine eşit yer verilmesi, öğretmenöğrenci boyutu üzerine çalışma yapılması, SOKÜM farkındalığı kazandırılması, ders materyallerinde yer alan görsel ve etkinliklerin öğrencilerin seviyelerine uygunluğuna dikkat edilmesi, ders kitapları ve notlarındaki yazım ve noktalama yanlışlarına dikkat edilmesi gerektiğine dikkat çekilmiştir.

Açık ve örgün eğitim Sosyal Bilgiler ders kitapları ve öğretim programında Somut Olmayan Kültürel Miras öğelerinin incelenmesi konusuna dayanan bu çalışma da, eğitimin sosyal bilgiler alanında olup milli kültürün korunmasını öncelemektedir. İlk incelenen lisansüstü tezden farklı olarak, ilgili konuyu açık öğretim kitaplarında da ele alması orijinal bir çalışma olmasına katkı sağlamaktadır.

\section{Akcaoğlu, C. (2017). Somut Olmayan Kültürel Miras ve Yabancı Dil Olarak Türkçe Öğretiminde Kullanımı. Hacettepe Üniversitesi Türkiyat Araştırmaları Enstitüsü, Yüksek Lisans Tezi, Ankara.}

Çalışmanın, UNESCO'nun Somut Olmayan Kültürel Miras Listesi'nde yer alan kültürel ögelerin, yabancı dil olarak Türkçe kullanımı konusunda, Yedi İklim Türkçe öğretim seti ve Yeni Hitit Türkçe öğretim setinde ne kadar ve nasıl kullanıldığını tespit etmek ve bu ögelerle ilgili olarak önerilerde bulunmak amacıyla yapıldığı ifade edilmiştir. Günümüzde yabancı dil olarak Türkçe öğretiminin yaygınlaştığ 1 , bu alanda üniversitelerde programlar açıldığı ve çok sayıda bilimsel çalışma yapıldığ belirtilmiştir. Kültür ve dilin iç içe olduğu, bu nedenle dil öğretimi yapılırken sadece dil bilgisi konularının öğretilmesinin düşünülemeyeceği açıklanmıştır. Dil öğretiminde kültür aktarımının vazgeçilmez bir konumda olduğu vurgulanmıştır. Bu çalışmada İnsanlığın Somut Olmayan Kültürel Mirası Türkiye Listesi'nde yer alan unsurların, yabancı dil olarak Türkçe öğretiminde kullanılan Yunus Emre Enstitüsünün yayımladığı Yedi İklim Türkçe öğretim seti ile Ankara Üniversitesinin çıkardığı Yeni Hitit setinde tespit edilmeye çalışıldığı ifade edilmiştir. Kitaplarda yer alan dinleme metinlerinin inceleme alanının dışında tutulduğu vurgulanmıştır. Türkiye İnsanlığın Somut Olmayan Kültürel Mirası Listesi'nde 2017 yılı itibariyle yer alan Meddahlık Geleneği (2008), Mevlevi Sema Törenleri (2008), Âşıklık Geleneği (2009), Karagöz (2009), Nevruz (Azerbaycan, Hindistan, İran, Kırgızistan, Özbekistan ve Pakistan ile ortak dosya, 2009), Geleneksel Sohbet Toplantıları (Yaren, Barana, Sira Geceleri ve diğer, 2010), Alevi-Bektaşi Ritüeli Semah (2010), Kırkpınar Yağlı Güreş Festivali (2010), Geleneksel Tören Keşkeği (2011), Mesir Macunu Festivali (2012), Türk Kahvesi ve Geleneği (2013), Ebru: Türk Kağıt Süsleme Sanatı (2014), İnce Ekmek Yapımı ve Paylaşımı Geleneği: Lavaş, Katrıma, Jupka, Yufka (Azerbaycan, İran, Kazakistan, Kırgızistan ve Türkiye ile ortak dosya) (2016), Geleneksel Çini Sanatı (2016) unsurları göz önüne alınarak sınıflama yapılmıştır.

Çalışma, "Kültür ve Kültürel Miras”, "Kültürel Süreçler”, "Kültür Çeşitleri”, "UNESCO Dünya Mirası Listeleri”, "Yabancı Dil Öğretiminde Kültür ve Kültür Aktarımı” ana başlıkları altında ele alınmaktadır. Çalışma sonucu elde edilen bulgular iki farklı tabloda sunulmuştur. İlk tabloda Yedi İklim ve Yeni Hitit Türkçe öğretim setlerinde somut olmayan kültürel mirasın nasıl ve ne kadar kullanıldığı, on dört kültürel mirasın kitaplardaki etkinlik, görsel, metin sayıları verilerek tespit edilmeye çalışılmıştır. Tablodaki bilgiler değerlendirildiğinde Yedi İklim öğretim setinde İnsanlığın Somut Olmayan Kültürel Mirası Türkiye Listesi'nde yer alan "Kırkpınar Yağlı Güreş Festivali”, "Geleneksel Tören Keşkeği”, "Mesir Macunu Festivali" ögelerine yer verilmediği, listede yer alan unsurlara toplamda 39 kere yer verildiğ $i$ tespit edilmiştir. Yeni Hitit setinde ise "Âşıklı Geleneği", "Karagöz", "Nevruz", "Kırkpınar Yağlı Güreş Festivali" ve "Ebru" ögelerine birer kez yer verildiği tespit edilmiştir. İkinci tabloda Yunus Emre Enstitüsünün yayımlamış olduğu Yedi İklim Türkçe öğretim setinde 39 etkinliğe, Ankara Üniversitesi 
TÖMER'in çıkardığı Yeni Hitit Türkçe öğretim setinde sadece 5 etkinliğe yer verildiği belirtilmiştir. İnsanlığın Somut Olmayan Kültürel Mirası Türkiye Listesi'nde yer alan ögelerin kullanıldığı etkinliklere dil düzeyleri açısından bakıldığında, âşıklık geleneği ve Türk kahvesi geleneği ile ilgili etkinliklerin dengeli bir dağılım gösterdiği, Karagöz’le ilgili etkinliklerde ise bir yığılma söz konusu olduğu tespit edilmiştir.

Dilin kitapların dışında da var olduğu belirtilerek dil öğretiminin kitaplara yapılacak eklerle veriminin artacağı düşünülerek kültürel unsurlara dikkat çekildiği belirtilmiştir. Yabancı dil öğretiminde sadece kitaba bağlı kalınmaması, bu nedenle de Türklerin günlük yaşamında yeri olan unsurların da vurgulanması gerektiği açıklanmıştır. Kitaplarda ve derslerde, öğretim amacıyla hazırlanmamış özgün metin ve malzemelerin kullanımının, ana dil konuşurlarıyla paylaşımlarının ve ortaklıklarının olması nedeniyle öğrenicilere hedef dili kullanma konusunda özgüven aşılayacağ 1 ifade edilmiştir.

Somut Olmayan Kültürel Miras listesinde yer alan unsurların, yabancı dil olarak Türkçe öğretiminde kullanımı konusuna dayalı tez çalışması, Türk kültürünün maddi ve manevi ayağının dil öğretiminde birlikte ele alınımı noktasında dikkat çekici olup orijinal bir çalışma özelliğini kazanmıştır. Türkçeyi yabancı dil olarak öğrenen ve dolayısıyla Türk kültürüyle tanışan bireylere, Türk kültürüne özgün öğelerin tanıtılması eylemi, dil öğrenimini tamamlayıc1 en önemli unsur olacağı düşünülmektedir. Nitekim herhangi bir dil, o dilin milletinin ya da toplumunun özgün, tarihi kültürü ile yoğrulmuştur. Milli ve evrensel değerleri kültüre taşıma, kültürü nakletme işi de yine o dile özgü bir nitelik olacaktır. O halde, yabancı bir dil öğrenimi aşamasında, mutlaka o dile ait kültürel mirasın da temel unsurlarının bilinmesi, ögrenilmesi dil eğitimin önemli basamaklarından biri olacaktır. Bu noktada tez çalışması, SOKÜM bağlamında ilişkilendirilerek alanında ilki temsil etmesi bakımından dikkate değerdir.

\section{Makaleler}

Kolaç, E. (2009). "Somut Olmayan Kültürel Mirası Koruma, Bilinç ve Duyarlılık Oluşturmada Türkçe Eğitiminin Önemi”. Millî Folklor, Y11 21, Sayı 82, ss: 19-31.

Kutlu, M. M. (2009). "Somut Olmayan Kültürel Mirasın Korunmasında Eğitime Yönelik İlk Adım: Halk Kültürü Dersi”. Milli Folklor, Y11 21, Say1 82, ss: 13-18.

Burgul, F. (2012). "Neşet Ertaş'ın Hayatının Öğretiminde Yaratıcı Drama Yönteminin Kullanılmasının Türk Dili ve Edebiyatı Öğretmen Adaylarının Kültürel Mirasa İlişkin Farkındalıklarına Etkisi”. Yaratıcı Drama Dergisi, 7(14), ss: 80-94.

Çengelci, T. (2012). "Sosyal Bilgiler Öğretim Programında Somut Olmayan Kültürel Mirasın Yeri”. Uludağ Üniversitesi Eğitim Fakültesi Dergisi, 25 (1), ss: 185-203.

Yılmaz, A. (2012). "İlköğretim Okulları Seçmeli Halk Kültürü Dersi Öğretim Programlarının Sınıflar Düzeyinde Karşılaştırılması”. Millî Folklor, Y11 24, Sayı 93, ss: 112-124.

Arıkan, İ., \& Doğan, Y. (2013). "İlköğretim 7. Sınıf Öğrencilerinin Kültürel Mirasla İlgili Başarı Düzeyleri ve Tutumlarının Bazı Değişkenlerce İncelenmesi (Adıyaman Örneği)". Adıyaman Üniversitesi Sosyal Bilimler Enstitüsü Dergisi, Y11: 6, Sayı: 15, ss: 29-64.

Çetin, T., \& Gürgil, F. (2013). "İlköğretim Öğrencilerinin Halk Kültürü Dersi Uygulamalarına İlişkin Görüşleri”. Zeitschrift für die Welt der Türken, Journal of World of Turks, Vol. 5, No. 2, ss: 73-86. Okur, A. (2013). "Millî Kültür ve Folklorun Türkçe Ders Kitapları Aracılığıyla Aktarımı". Adıyaman Üniversitesi Sosyal Bilimler Enstitüsü Dergisi Türkçenin Eğitimi Öğretimi Özel Sayısı, Yı1: 6, Sayı: 11, ss: $877-901$.

Teke, S. G. (2013). "Geleneksel Tarzlar, Modern Modeller: Resmi, Resmi Olmayan Eğitim ve Somut Olmayan Kültürel Miras”. Millî Folklor Dergisi, (100), ss: 31-39.

Ünal, F. (2013). "İlköğretim Sosyal Bilgiler Ders Kitaplarında Yer Alan Halk Kültürü Ögelerinin Değerlendirilmesi”. Adıyaman Üniversitesi Sosyal Bilimler Enstitüsü Dergisi, Y1l: 6, Sayı: 14, Sosyal Bilgiler Öğretimi Özel Sayıs1, ss: 611-641.

Yeşilbursa, C. C. (2013). "Altıncı Sınıf Öğrencilerinin Somut Kültürel Mirasa Yönelik Görüşleri”. Kastamonu Eğitim Dergisi, Cilt 21, No 2, ss: 405-420.

Akhan, N. E. (2014). "Sosyal Bilgiler Derslerinde Somut Olmayan Kültürel Miras Öğretimi". International Online Journal of Educational Sciences, 6 (3), ss: 722-736.

Çençen, N., \& Berk, N. A. (2014). "İlköğretim 6. ve 7. Sınıf Sosyal Bilgiler Programlarında Türk Halk Kültürü Oğelerinin Yeri ve Önemi”. e - Kafkas Eğitim Araştırmaları Dergisi, 1(3), ss: 13-25. 
Meydan, A., \& Akkuş, A. (2014). "Sosyal Bilgiler Öğretiminde Müze Gezilerinin Tarihi ve Kültürel Değerlerin Kazandırılmasındaki Önemi”. Marmara Coğrafya Dergisi, Sayı 29, ss: 402-422.

Üstten, A. U. (2014). "Türk Romanının Somut Olmayan Kültürel Miras Aktarımı Açısından İncelenmesi”. Ana Dili Eğitimi Dergisi, 2(3), ss: 20-31.

Aral, A. E. (2015). "Uygulamalı Halk Bilimi Açısından Eğitim Sürecinde Dede Korkut”. Türk Dünyası İncelemeleri Dergisi, 15/2, ss: 123-138.

Külcü, Ö. T. (2015). “Kültürel Miras Kavramının Eğitim Açısından Önemi”. Akademia Disiplinlerarası Bilimsel Araştırmalar Dergisi 1 (1), ss: 27-32.

Aral, A. E. (2016). "Gazi Üniversitesi ve Türkiye de Bir İlk Örgün ve Yaygın Eğitimde Somut Olmayan Kültürel Miras Kürsüsü”. Milli Folklor.

(2016). “'Hayat Bilgisi’ ve 'Halk Kültürü' Dersleri Üzerinden Kültür Koruma Yaklaşımlarının Karşılaştırmalı Değerlendirmesi”. Millî Folklor, Y11 28, Sayı 112, ss: 107-119.

Akyol, P. K. (2016). "Somut Olmayan Kültürel Mirasın Örgün Eğitime Uygulanması: Ağaraştırması (Webquest) Örneği”. Millî Folklor, Y11 28, Say1 111, ss: 149-170.

Avc1, M., \& Memişoğlu, H. (2016). "Kültürel Miras Eğitimine İlişkin Sosyal Bilgiler Öğretmenlerinin Görüşleri”. İlköğretim Online, 15(1).

Çağlayan, T. K., \& Karakuş C. (2016). "Hayat Bilgisi Öğretim Programında ve Ders Kitaplarında Somut Olmayan Kültürel Mirasin Yerinin İncelenmesi". The Journal of Academic Social Science Studies, Doi number:http://dx.doi.org/10.9761/JASSS3373, Say1: 45, ss: 393-405.

Pehlivan, A., \& Kolaç, E. (2016). "Açık - Örgün Eğitim Sosyal Bilgiler Ders Kitapları ve Öğretim Programında Somut Olmayan Kültürel Miras Ögeleri”. Turkish Studies International Periodical for the Languages, Literature and History of Turkish or Turkic, Volume 11/19, p. 655-670.

Savaşkan, V. (2016). "Ortaöğretim Türk Edebiyatı Program ve Ders Kitaplarının Somut Olmayan Kültürel Miras Ögeleri Açısından İncelenmesi”. Erzincan Üniversitesi Eğitim Fakültesi Dergisi, Cilt 18, Say1 2, ss: 1302-1323.

Gürel, D., \& Çetin, T. (2017). "Ortaokul Öğrencilerinin Somut Olmayan Kültürel Mirasa Yönelik Tutumları”. In ICPESS (International Congress on Politic, Economic and Social Studies) (No. 2).

\section{Bildiriler}

Sağlam, S. (2011 ). "IV. Uluslararası Dünya Dili Türkçe Sempozyumu Orta Öğretim Türk Edebiyatı Ders Kitaplarında Somut Olmayan Kültürel Mirastan Yararlanılması Üzerine Bir Değerlendirme".

Solmaz, E. (2011). "Orta Öğretim Türk Edebiyatı Ders Kitaplarında Somut Olmayan Kültürel Miras Unsurlarından Yararlanılması Üzerine Bir Değerlendirme”. Presented at the V. Uluslarası Dünya Dîli Türkçe Sempozyumu .

Acat, M. B., Çimen, E., \& Çiftçi, Ş. K. (2015). "Türk Dünyasında Somut Olmayan Kültürel Mirasın Matematik Öğretiminde Kullanılması”. Presented at the I. Uluslararası Türk Dünyası Çocuk Oyun ve Oyuncakları Kurultayı .

Tokcan, H., Hacer, O., \& Yasemin, K. (2015). "5 Sinıf Sosyal Bilgiler Ders Kitaplarında Somut Olmayan Kültürel Miras Öğeleri” . Presented at the 24. Ulusal Eğitim Bilimleri Kongresi.

Gürel, D., \& Çetin, T. (2016). "Türkiye de Somut Olmayan Kültürel Miras ve Bunun Sosyal Bilgiler Ders Kitaplarına Yansıması". Presented at the 5. Uluslararası Sosyal Bilgiler Eğitimi Sempozyumu, Denizli.

Güven, A. Z. (2016). "Ortaokul Türkçe Ders Kitaplarının Somut Olmayan Kültürel Miras Unsurları Açısından İncelenmesi”. Presented at the 25. Ulusal Eğitim Bilimleri Kongresi, Antalya.

Kutlu, M. M. (2016). "Somut Olmayan Kültürel Miras ve Eğitim”. Presented at the Panel, Gaziantep. Gürel, D., \& Çetin, T. (2017). "Ortaokul Öğrencilerinin Somut Olmayan Kültürel Mirasa Yönelik Tutumları". Presented at the İnternational Congress on Political, Economic and Social Studies, Saraybosna.

(2017). "Ortaokul Öğrencilerinin Somut Olmayan Kültürel Mirasa Yönelik Görüşlerinin Kültürel Mirasa Duyarlılık Açısından Değerlendirilmesi”. Presented at the VI. Uluslararası Sosyal Bilgiler Eğitimi Sempozyumu, Eskişehir.

Kutlu, M. M. (n.d.). "Somut Olmayan Kültürel Mirasın Örgün ve Yaygın Eğitimde Değerlendirilmesi”. Presented at the KKTC SOKÜM Ulusal Konseyi Toplantıs1, Lefkoşa. 


\section{Değerlendirme}

Çalışma sonunda 3 tez, 25 makale ve 10 bildiri tespit edilmiştir. Tez çalışmaları incelendiğinde 2 çalışmanın Sosyal Bilgiler dersiyle ilgili olduğu diğer tez çalışmasının da yabancılara Türkçe öğretimi konusunda yapıldığı görülmüştür.

Çalışmalar, Milli Eğitim Bakanlığ tarafından hazırlanan veya tavsiye edilen yayınevlerine ait ders ve çalışma kitaplarında Somut Olmayan Kültürel Mirasın yerini belirlemek amacıyla yazılmıştır. Çalışmalarda ders kitaplarında SOKÜM boyutlarının kazanımlara göre dağılımı sınıflar düzeyinde incelenmiştir. Makalelerde sosyal bilgiler, edebiyat, halk kültürü ve Türkçe derslerinin öğretim programlarıyla birlikte ders kitaplarının incelendiği tespit edilmiştir. Sosyal bilgiler dersiyle ilgili çalışmaların ağırlıkta olduğu görülmüştür. Türkçe Öğretim Programı’nın genel amaçlarında,

ögrencilerin millî, manevi, ahlaki, tarihî, kültürel, sosyal, estetik ve sanatsal değerlere önem vermelerini sağlamak; millî duygu ve düşüncelerini güçlendirmek hedeflenmektedir. Buradan hareketle, konuyla ilintisi bağlamında, üniversitelerin Eğitim Fakülteleri Türkçe Eğitimi bölümlerinde konuyla ilgili fazla çalışma yapılmadığı görülmüştür. Diğer taraftan, makalelerde somut olmayan kültürel mirasla ilgili öğretmen ve öğrenci görüşlerini belirleme çalışmalarına da yer verilmiştir. Makalelerde halk kültürü dersinin temel gerekçeleri, "Halk Kültürü Dersi Öğretim Programı" hazırlık süreçleri, dersin yapısı ve gelecekte yapılması gerekenler konularına değinilmiştir.

Yapılan çalışmaların Türkçe, Sosyal Bilgiler ve Halk Kültürü derslerinin ortak hedefi olan, milli kültürü/halk kültürünü, SOKÜM bağlamında, koruma altına alarak, onu gelecek kuşaklara tanıtmak, naklini sağlamak amacıyla ele alındığı görülmüştür.

\section{Sonuç}

Türk kültürü, kökleri oldukça eski dönemlere uzanan, göçer evli kültürden yerleşik hayata geçiş süreçleri dâhil pek çok zengin kültürel hazineyi bünyesinde barındıran ve günümüze gelişerek bazen değişerek bazen de dönüşerek taşına gelen köklü bir kültürdür. Türk kültürü ve dahilinde tüm dünya genelinde milli kültürlerin korunup yaşatılması ve aktarılması bağlamında hedefleri olan SOKÜM

Sözleşmesi, bilindiği üzere oldukça yakın bir tarihe aittir. Bu çalışmada, özellikle Türkiye'nin taraf devlet olduğu 2006 tarihinden itibaren ülkede, Türk kültürünü, yaşayışını, gelenek ve göreneklerini eğitim ve SOKÜM bağlamında ele alan nitelikli çalışmaların yapıldığı tespit edilmiştir, ancak bu çalışmaların Türk kültür hazinesinin enginliği düşünüldüğünde henüz sınırlı sayıda olduğu görülmüsstür. Öyle ki, ilgili alana katkı sağlayacak olan yeni bilimsel çalışmaların genç nesilleri aydınlatmada ve onlarda konuyla ilgili farkındalık yaratmada ve de en önemlisi tüm bunların Türk kültürünün geleceğine önemli katkıda bulunacağı düşünülmektedir. Diğer taraftan, SOKÜM konusunda, özellikle Z kuşağında milli duyarlılık artırılmalıdır. Bunun için de, ülkede eğitim - öğretim kurumlarında sistemli ve planlı olarak bu konunun eğitimi verilmeli, zorunlu ders olarak MEB okullarında bir başka ifadeyle örgün eğitimde yer almalıdır.

\section{Kaynaklar}

Anadol, C., Abbasova, F., \& Abbasl1, N. (2002). Türk Kültür ve Medeniyeti. Bilge Karınca Yayınları, İstanbul.

Aral, A. E. (2016). "Hayat Bilgisi ve Halk Kültürü Dersleri Üzerinden Kültür Koruma Yaklaşımlarının Karşılaştırmalı Değerlendirmesi”. Millî Folklor, Y11 28, Sayı 112, ss: 107-119.

Artun, E. (2000). Halk Kültürü ve Folklorun Türk Kültüründeki Yerine Kültürel Değişim ve Gelişim Açısından Bakış. Adana Halk Kültürü Araştırmaları.

Akyol, P. K. (2016). "Somut Olmayan Kültürel Mirasın Örgün Eğitime Uygulanması: Ağaraştırması (Webquest) Örneği". Millî Folklor, Y11 28, Say1 111, ss: 149-170.

Gökalp, Z. (2013). Kültür ve Medeniyet Türkleşmek, İslamlaşmak, Muasırlaşmak, Gençlik Kitabevi Yayınlar1, (3. Baskı) Konya.

Kafeslioğlu, İ. (2011). Türk Milli Kültürüu. Ötüken Neşriyat, (32. Basım) İstanbul.

Kaplan, M. (1992). Kültür ve Dil. Dergah Yayınları, (7. Baskı) İstanbul.

Kolaç, E. (2009). "Somut Olmayan Kültürel Mirası Koruma, Bilinç ve Duyarlılık Oluşturmada Türkçe Eğitiminin Önemi.” Millî Folklor, Y11 21, Say1 82, s. 19-31. 
Kutlu, M. M. (2009). "Somut Olmayan Kültürel Mirasın Korunmasında Eğitime Yönelik İlk Adım: Halk Kültürü Dersi.” Milli Folklor, Y11 21, Say1 82, s. 13-18.

Oğuz, Ö. vd. (2005). "Somut Olmayan Kültürel Mirasın Korunması Sözleşmesi”. Milli Folklor, Sayı 65, s. 163-171.

Oğuz, Ö. (2008). “UNESCO ve Geleneğin Ustaları”. Milli Folklor, Y11 20, Sayı 72, s. 5-10. , (2009). "Somut Olmayan Kültürel Miras ve Kültürel İfade Çeşitliliği”. Millî Folklor, Y1l 21, Say1 82, s.6-12. , (2013). Somut Olmayan Kültürel Miras Nedir?, Geleneksel Yayıncılık, Ankara. vd. (2014). Türk Halk Edebiyatı El Kitabı, Grafiker Yayınlar1, 11. Bask1, Ankara.

Okur, A. (2013). "Millî Kültür Ve Folklorun Türkçe Ders Kitapları Aracılığıyla Aktarımı”. Adıyaman Üniversitesi Sosyal Bilimler Enstitüsü Dergisi Türkçenin Eğitimi Öğretimi Özel Sayıs1, Yı1: 6, Sayı: 11, ss. 877-901.

Topçu, N. (2016). Kültür ve Edebiyat. Dergah Yayınları (11. Baskı) İstanbul.

Türkçe Sözlük, (1998). Türk Tarih Kurumu Basım Evi, Ankara.

\section{İnternetKaynakları}

https://scholar.google.com.tr/scholar?hl=tr\&q=Somut + olmayan $+\mathrm{k} \% \mathrm{C} 3 \% \mathrm{BClt} \% \mathrm{C} 3 \% \mathrm{BCrel}+$ miras \&lr $=\& o q=(E T: 12.03 .2017-08.05 .2017)$

https://tez.yok.gov.tr/UlusalTezMerkezi/tezSorguSonucYeni.jsp

(ET:

http://akademik.yok.gov.tr/AkademikArama/view/searchResultview.jsp (ET:04.05.2017-13.05.2017)

http://ttkb.meb.gov.tr (ET: 18.05.2017)

http://www.millifolklor.com/ (ET: 24.03.2017)

Güncel Türkçe Sözlük, http://tdk.gov.tr/ (ET: 20.05.2017) http://turkoloji.cu.edu.tr/HALKBILIM/4.php 